\title{
Nonlinear Kinetic and Equilibrium Adsorption Isotherm Study of Cadmium (II) Sorption by Dacryodes edulis Biomass
}

\author{
*L. C. Overah \\ Department of Chemistry, Faculty of science, Delta State University, Abraka, Nigeria \\ [*Corresponding Author: E-mail: overahrubyisaac@yahoo.com; $[$ : +2348166185591]
}

\section{ABSTRACT}

The kinetics and equilibrium adsorption isotherm of cadmium (II) adsorption onto Dacryodes edulis (native peer seed) biomass was studied using a nonlinear approach, which is unpopular but proven in some literature to be more reliable and easier. In optimizing the process, about $98 \%$ removal of the cadmium ion was achieved within five minutes at $\mathrm{pH} 7$ by contacting just $30 \mathrm{mg}$ of the Dacryodes edulis seed biomass with the adsorbate solution of a concentration of $100 \mathrm{mg} / \mathrm{L}$. Non-linear investigation of the kinetics and adsorption isotherms of the process was done using the $\mathrm{R}$ console statistical and computing software. The results indicated that the Elovich mechanism and the Freundlich adsorption isotherm most suitably described the kinetics and adsorption isotherm, respectively, of the process as provided by their least values of the sum of squared residuals (SSR). This outcome implied a chemical adsorption (chemisorption) mechanism and a multi-layer coverage by the cadmium ions on heterogeneous active sites of the biomass surface with a Freundlich constant or capacity factor, $\mathrm{Kf}$ of $27.83 \mathrm{mg} \mathrm{g}-1$, heterogeneity factor, $1 / \mathrm{n}$ of 0.2614 and Elovich constants, $\alpha$ and $\beta$ of $7.0 \mathrm{mg} \mathrm{g}-1 \mathrm{~s}-1$ and $1.0 \mathrm{~g} \mathrm{mg}-1$, respectively. These findings indicate that Dacryodes edulis seed biomass has a good potential for cadmium (II) adsorption.

Keywords: Dacryodes edulis, Elovich kinetic model, Freundlich isotherm, Langmuir isotherm, Nonlinear.

\section{INTRODUCTION}

Heavy metals in water result mainly from rapid industrialization and technology advancement and is a global environmental palaver demanding quick and careful attention because of their toxicity and bioaccumulation ability. The metals of most concern are cadmium, uranium, chromium, mercury, zinc, selenium, lead, gold, copper, silver, arsenic and nickel. These metals may emanate from the disposal of sludge, ore refining, radioactive materials processing, fly ashes produced from incinerators, metal plating and the production of things like electrical equipment, alloys, paints, batteries, preservatives and pesticides. In the past decades, the methods commonly used to remove or reduce the levels of these metal ions in aqueous systems are namely: coagulation, chemical precipitation, ion exchange, solvent extraction and reverse osmosis (Rich and Cherry, 1987). However, these conventional methods have their various setbacks such as much time consumption, high energy and reagent requirement, high cost and generation of secondary wastes, which require even more careful treatment and disposal. This has necessitated the search for cheaper and ecofriendly methods for treatment of aqueous solutions and effluents containing these metals. Biosorption is this alternative method which is based on the capacities of different materials of biological origin (including microorganisms like fungi, algae and bacteria) to bind metal ions (Volesky, 1990). Apart from its cheapness, greater efficiency and minimization of the issue of secondary pollution, biosorption has a special advantage of regeneration of biosorbent, which makes it possible to recover the metal and reuse the biosorbent for more adsorption cycles (Volesky, 1999).

Two phases exist in the biosorption process; a liquid phase usually the adsorbate solution bearing the metal ions and a solid phase which is the biosorbent material. The affinity of the adsorbent for the adsorbate causes attraction and bonding of the adsorbate to the adsorbent by one of the various mechanisms such as ion 


\section{Overah: Nonlinear Kinetic and Equilibrium Adsorption Isotherm Study...}

exchange, micro precipitation, complexation or chelation. The binding process proceeds until equilibrium is attained between the amounts of the sorbate bound on the adsorbent and that remaining in the solution. Thus, the sorbate ions are distributed between both phases and the extent of distribution is dependent on the degree of the adsorbent's affinity for the adsorbate.

Recently, biosorption experiments have been carried out using agricultural materials, which are waste products or by-products from large-scale agricultural processes. For instance, activated sludge from the treatment of sewage (Hammaini et al., 2007), the waste Mycelia from the fermentation process, biosolids (Sarioglu et al., 2009), solid residues from olive mills (Pagnanelli et al., 2001), and aquatic macrophytes (Keskinkan et al., 2004). The adsorption characteristics of copper, zinc and lead on a submerged aquatic plant, Myriophyllum spicatum, was studied by Keskinkan et al. (2004). The adsorption capacities were $46.69 \mathrm{mg} / \mathrm{g}$ for lead, $15.59 \mathrm{mg} / \mathrm{g}$ for zinc and $10.37 \mathrm{mg} / \mathrm{g}$ for copper. Eyenubo and Overah (2018) studied cadmium adsorption of Musa paradisiaca stalk and obtained an adsorption capacity of $960 \mathrm{mg} / \mathrm{g}$. Also, the performance of Calotropis procera leaf biomass was evaluated for cadmium adsorption by Babalola et al. (2011), and approximately 9.00 $\mathrm{mg} / \mathrm{g}$ was obtained as the maximum adsorption capacity. In this study, the capacity of Dacryodes edulis biomass prepared from native pear seed for cadmium (II) adsorption from aqueous solution was investigated. Besides, the kinetics and equilibrium isotherms were investigated through the application of some established models to elucidate the mechanism by which the process takes place.

These models are represented by nonlinear equations, which are usually linearized and plotted accordingly to obtain a correlation coefficient that determines the fitness of the data to the model. The necessary parameters are calculated from the intercepts and slopes of such plots. However, nonlinear regression has been proved a better alternative to linear regression because it provides the most flexible functionality for curve-fitting (Ogee et al., 2013). Besides, the linearization of these kinetic and isotherm equations can statistically distort the interpretation of the distributions of an experimental error (Osmari et al., 2013). The implication is that the ordinary least - squares assumptions of a normal distribution of measurement or experimental errors and consistency in error variance are rendered invalid (Allen et al. 2003; Parimal et al. 2010; Osmari et al., 2013). Furthermore, there are several published studies which have analysed and compared the results of using both nonlinear and linear regressions for elucidating adsorption isotherms, kinetics and thermodynamics and the general conclusion is that the former usually provides better and more accurate results (Kumar and Sivanesan 2005a,b; Parimal et al., 2010 and Bolster and Hornberger, 2007).

Therefore, this work utilizes the nonlinear approach in fitting both the equilibrium and kinetic experimental adsorption data into a routine nonlinear scheme available in the $R$ statistical computing environment. The necessary parameters are automatically generated with the plots and the fitness to a particular model is determined by examining the smallness of the residuals. To the best of our knowledge, the native pear seed has not been used for $\mathrm{Cd}$ (II) sorption studies except in our earlier work testing the adsorbent on $\mathrm{Pb}$ (II) removal and using a linear approach to study its kinetics and adsorption isotherms (Overah and Odiachi, 2017). It is hoped, therefore, that studying the applicability of Dacryodes edulis seed biomass, a low-cost adsorbent which in its season constitutes a great environmental nuisance, will add to the sorption data bank and that the less common nonlinear approach which proves to be a quicker, easier and yet more accurate tool for kinetic and adsorption isotherm modelling becomes a more preferable option for most researchers of similar interest than the usual and common linear approach. 


\section{MATERIALS AND METHODS}

Sample Collection and Preparation

Dacryodes edulis seeds were collected from parts of Ogwashi-uku and Agbor villages both in Delta State, Nigeria. The seeds were first washed twice with tap water to rid them of sand and dirt and then thoroughly rinsed with de-ionized water. They were thereafter, air-dried for seven days, pulverized and sieved using a $100 \mu \mathrm{m}$ mesh screen. The homogenized biomass was activated by soaking in $0.1 \mathrm{M} \mathrm{HCl}$ for 24 hours after which it was washed and filtered four times to achieve a neutral $\mathrm{pH}$. The biomass was then dried again, re-powdered and stored in an airtight polythene bag.

\section{Preparation of Stock Solution}

A $1000 \mathrm{mg} / \mathrm{L}$ stock solution of cadmium (II) was prepared by weighing $2.7442 \mathrm{~g}$ of cadmium trioxonitrate $(\mathrm{V})$ tetrahydrate $\left(\mathrm{Cd}\left(\mathrm{NO}_{3}\right)_{2} .4 \mathrm{H}_{2} \mathrm{O}\right)$ and dissolving it in de-ionized water in a large beaker. The solution was quantitatively transferred to a 1 -litre standard volume flask and then further diluted to the mark with de-ionized water. The actual concentration which was determined by a Buck scientific Flame Atomic Absorption Spectrometer (FAAS) model 2004 (Germany), was used for calculations involving the serial dilutions.

\section{Adsorption Studies}

Adsorption experiments to study the kinetics of the process were carried out in batches under varied contact time from 5 minutes to 1440 minutes with $50 \mathrm{~mL}$ of $50 \mathrm{mg} / \mathrm{L} \mathrm{Cd}$ (II) solution at $28{ }^{\circ} \mathrm{C}$ and $\mathrm{pH} 7$ using a biosorbent dose of 30 $\mathrm{mg}$. While the adsorption isotherm studies were performed also by batch experiments contacting $30 \mathrm{mg}$ of the adsorbent with $25 \mathrm{~mL} \mathrm{Cd}$ (II) solution whose concentration was varied from 10 to $100 \mathrm{mg} / \mathrm{L}$ for two hours at $28{ }^{\circ} \mathrm{C}$ and $\mathrm{pH} 7$. After contact, the suspension was filtered using Whatman No. 1 filter paper. The residual metal ion content of the filtrates was measured by AAS. The adsorption studies were carried out at pH 7 because the cadmium speciation model showed that the precipitation of $\mathrm{Cd}$ (II) ions at this $\mathrm{pH}$ was negligible under the given experimental conditions. Moreover, prior studies had shown that the effect of $\mathrm{pH}$ on $\mathrm{Cd}$ (II) sorption onto Dacryodes edulis was virtually insignificant.

\section{Statistical Analysis}

All data obtained from the study of the effect of $\mathrm{pH}$, contact time, adsorbent dose and initial $\mathrm{Cd}$ (II) ion concentration were analysed by making appropriate plots using the Origin 6.1 software, while the kinetic and equilibrium data analysis were done as described in the following subsections.

\section{Nonlinear Analysis of the Kinetics of the Adsorption Process}

To study the mechanism of the $\mathrm{Cd}$ (II) ions adsorption onto the adsorbent, four kinetic models were used to test the data from timedependent studies namely, the pseudo first-order, pseudo second-order, intraparticle diffusion and Elovich kinetic models.

Nonlinear plots of the amount of $\mathrm{Cd}$ (II) adsorbed at different time intervals, $q t$ against time, $t$ for the four kinetic models were made using a routine nonlinear scheme available in the ' $R$ ' statistical and computing environment. The " $R$ " console is used to make nonlinear plots of models from which the values of the corresponding parameters are generated ("R" Development Core Team, 2011). Each of the models was assessed by the sum of squared residuals (SSR). The best-suited model was then determined by comparing the values of the SSR of the models. The smaller the value of the SSR, the better the fitness of the model to the experimental data (Hamza et al., 2013). The values of the relevant kinetic parameters were generated automatically at the bottom of the $\mathrm{R}$ sheet.

\section{Nonlinear Analysis of the Adsorption Isotherms \\ Nonlinear plots of the amount of $\mathrm{Cd}(\mathrm{II})$ adsorbed at equilibrium, qe against the residual concentration of $\mathrm{Cd}$ (II), Ce for the Langmuir and Freundlich isotherm models were made and the}




\section{Overah: Nonlinear Kinetic and Equilibrium Adsorption Isotherm Study...}

fit of each model was assessed by the SSR. It is important to model the concentration-dependent data because it provides information that can be used for the comparison of the capacities of different adsorbents under different conditions of operation (Rifaqat \& Moonis, 2002).

The relationship between the cadmium ions concentration taken up by the adsorbent, $q e$ and the concentration remaining in the solution, $\mathrm{Ce}$ at a constant $\mathrm{pH}$ and temperature at equilibrium is described by the adsorption isotherms. In this work, the Langmuir and Freundlich isotherms were employed. The relevant parameters to each kinetic and adsorption isotherm (Table 1) were generated automatically by the 'R' software.

Table 1: Kinetic and adsorption isotherms models, their equations and related parameters.

\begin{tabular}{|c|c|c|}
\hline KINETIC MODEL & EQUATION & PARAMETERS \\
\hline Pseudo first-order & $\begin{array}{l}q_{t}=q_{e}\left(1-e^{-K_{1} t}\right) \\
k_{2} q_{e}^{2} t\end{array}$ & $q_{e}, k_{1}$ \\
\hline Pseudo second- order & $q_{t}=\frac{\overline{1+k_{2 q_{e}} t}}{1}$ & $q_{e}, k_{2}$ \\
\hline Elovich & $q_{t}=\frac{-}{\beta} \ln (\alpha \beta)+\bar{\beta} \ln t$ & $\alpha, \beta$ \\
\hline $\begin{array}{l}\text { Intra - particle diffusion } \\
\text { ADSORPTION ISOTHERM }\end{array}$ & $\begin{array}{l}q_{t}=k_{i d}(t)^{1 / 2}+C \\
\text { EQUATION } \\
\quad q_{m} b C_{e}\end{array}$ & $\begin{array}{c}k_{i d}, C \\
\text { PARAMETERS }\end{array}$ \\
\hline Langmuir & $\overline{1+b C_{e}}$ & $q_{m}, b$ \\
\hline Freundlich & $q_{e}=K_{f} C_{e}^{1 / n}$ & $K_{f, n}$ \\
\hline
\end{tabular}

\section{RESULT AND DISCUSSION}

\section{The Effect of $\mathrm{pH}$}

The uptake of Cd (II) by Dacryodes edulis at varied $\mathrm{pH}$ values is illustrated in Figure 1. The uptake of $\mathrm{Cd}$ (II) on Dacryodes edulis increased initially from 48.60 to $49.08 \mathrm{mg} / \mathrm{g}$ when the $\mathrm{pH}$ increased from 2 to 4 and only slightly (from 49.08 to $49.535 \mathrm{mg} / \mathrm{g}$ ) as the $\mathrm{pH}$ was further increased from 4 to 7 . This indicates that $\mathrm{pH}$ plays an insignificant role in $\mathrm{Cd}$ (II) uptake on Dacryodes edulis. However, previous studies by Eyenubo and Overah (2018) under nearly similar experimental conditions have shown that at $\mathrm{pH} 8$ and above, several insoluble cadmium (II) hydroxide species begin to precipitate. Therefore, throughout the rest of this study, the $\mathrm{pH}$ was kept constant at 7 where the $\mathrm{Cd}$ (II) removal process is certainly free from the contributions from precipitation of cadmium as hydroxides.

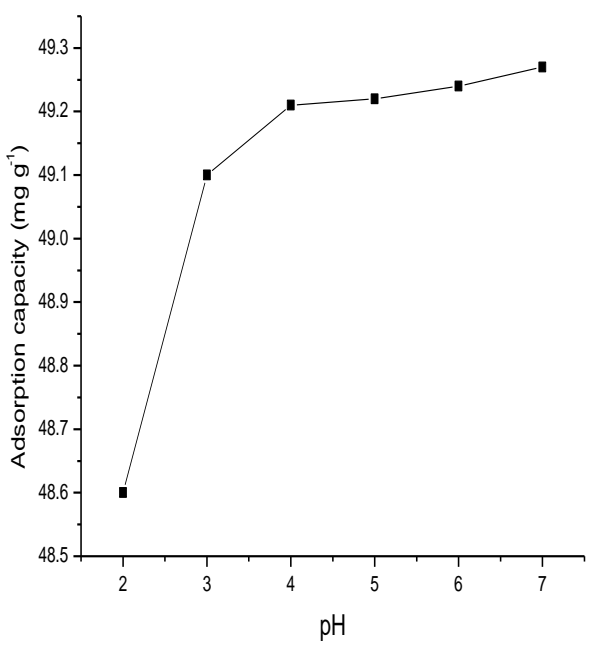

Figure 1: Effect of pH on the adsorption of $\mathrm{Cd}$ (II) by Dacryodes edulis seed waste biomass 


\section{Effect of Contact Time}

The adsorption capacity of Dacryodes edulis biomass for $\mathrm{Cd}$ (II) as a function of time (at pH 7) is displayed in Figure 2. The result shows that the biosorption of Cd (II) onto Dacryodes edulis is a rapid process reaching equilibrium at 150 minutes. After this time, there was only a slight increase in the amount of $\mathrm{Cd}$ (II) ions uptake up to 240 minutes. This implies a rapid initial rate of $\mathrm{Cd}$ (II) ions uptake followed by a slow rate of uptake. The slowing down of the process suggests that the active sites were being saturated with the ions.

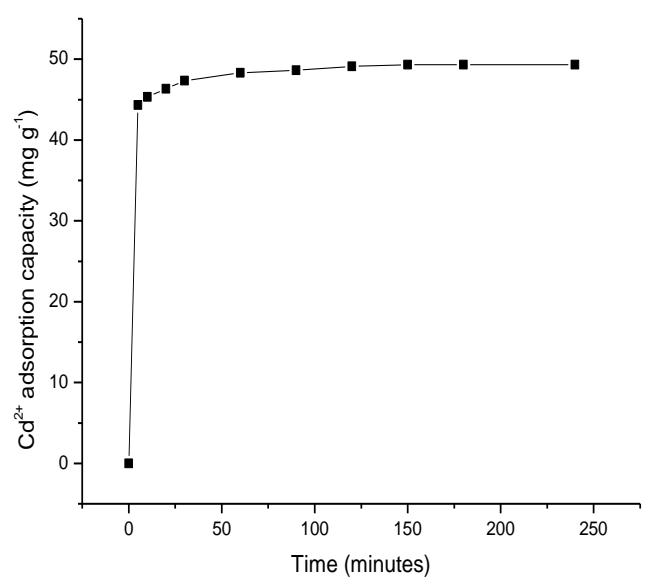

Figure 2: Effect of time on the adsorption capacity of Dacryodes edulis seed waste biomass for $\mathrm{Cd}(\mathrm{II})$ ions.

However, a very significant amount of $\mathrm{Cd}$ (II) ions (approx $45 \mathrm{mg} / \mathrm{g}$ ) was adsorbed within the first 5 minutes. This probably suggests that there is a strong affinity for the adsorbate by the adsorbent. After this time, there was only an insignificant increase in the amount of adsorbed ions. Therefore, the rest of the experiment was carried out at 5 minutes. Similar results were reported by Eyenubo and Overah (2018) for Cd (II) adsorption onto Musa paradisiaca biomass. Cd (II) adsorption onto Musa paradisiaca biomass was rapid in the first ten minutes after which further extension of the time yielded an insignificant increase in the amount adsorbed. Hynda and Rachida (2008) also reported initial rapid lead adsorption onto crude and biologically activated stems of dates. In the first ten minutes, $63.8 \%$ lead adsorption by the raw date stems was achieved while $97 \%$ was achieved using biologically activated date stems with only a slight and insignificant increase at times beyond ten and five minutes for both raw and activated biomass, respectively.

\section{Effect of Initial Cadmium (II) Concentration}

The result of the uptake of $\mathrm{Cd}$ (II) onto Dacryodes edulis biomass at varied initial metal ion concentrations is shown in Figure 3.

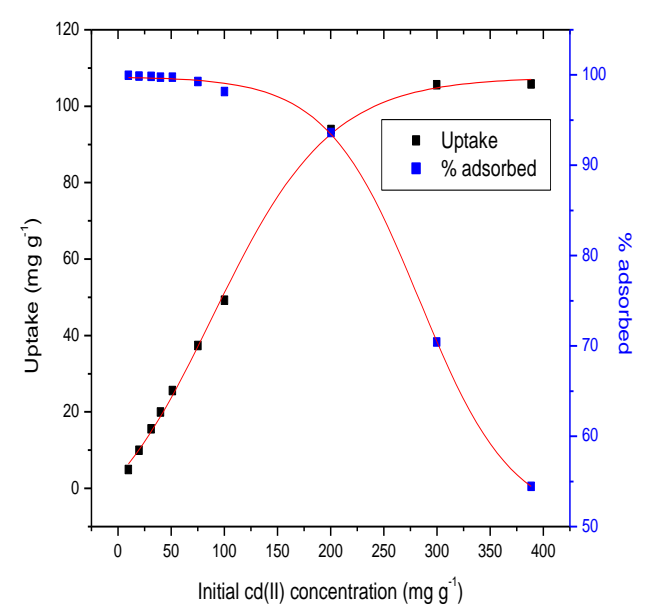

Figure 3: Effect of initial $\mathrm{Cd}(\mathrm{II})$ concentration on the uptake of the cd (II) ions onto Dacryodes edulis seed waste biomass.

The metal uptake increased from 4.898 to 105.81 $\mathrm{mg} \mathrm{g}^{-1}$ when the initial $\mathrm{Cd}$ (II) concentration was increased from $10 \mathrm{mg} / \mathrm{L}$ to $400 \mathrm{mg} / \mathrm{L}$ at a constant biomass dosage of $50 \mathrm{mg}$. This increase may be ascribed to the fact that when the initial $\mathrm{Cd}$ (II) concentration is high, there is a strong driving force, which helps to overcome the adsorbate ions' resistance to mass transfer from the aqueous phase to the solid-liquid interface. This implies that the adsorption sites on the adsorbent in the solution with a larger concentration will reach adsorption equilibrium more readily. However, the reverse is the case for percentage adsorbed. When the initial $\mathrm{Cd}$ (II) concentration is increased, the percentage adsorbed decreases due to saturation of binding 


\section{Overah: Nonlinear Kinetic and Equilibrium Adsorption Isotherm Study...}

sites at constant biomass dose. These trends of results have been previously reported (Babalola et al., 2011; Overah, 2011; Hamza et al., 2013). According to their reports, adsorption capacity or uptake increases with increase in initial metal ion concentration but percentage adsorption decreases with increasing initial metal ion concentration. This is in line with the outcome of this study.

\section{Nonlinear Analysis of the Kinetics of Cd (II) Adsorption onto Dacryodes edulis}

The results of the nonlinear kinetics study of the adsorption of $\mathrm{Cd}$ (II) onto Dacryodes edulis are shown in Figure 4.

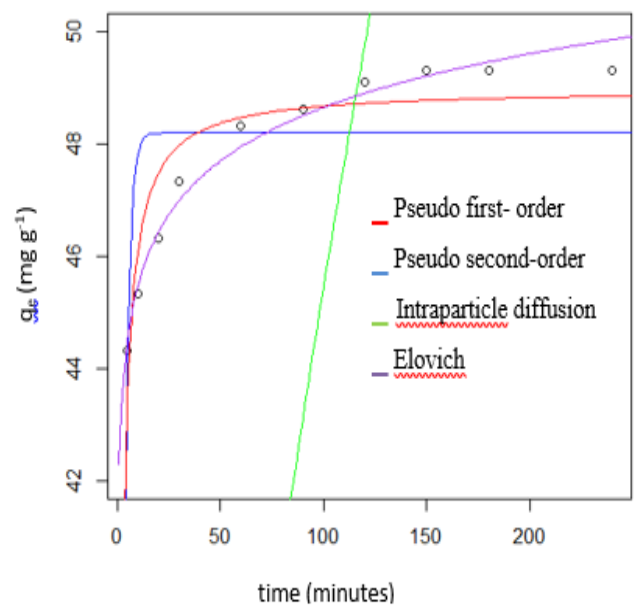

Figure 4: A nonlinear comparison of the four kinetics models for $\mathrm{Cd}$ (II) adsorption onto Dacryodes edulis seed waste biomass.

It is obvious from Figure 4 that the Elovich model provides a better fit as most of the data points fall on the Elovich curve (purple line). However, more concrete support is provided by the least value of the SSR for the Elovich model compared with those of the other models shown in Table 2. The implication of this is that the process occurs through a chemisorption mechanism.

\section{Nonlinear Analysis of the Adsorption} Equilibrium Isotherms

An adsorption isotherm is a mathematical model, which relates the adsorbate concentration left in the liquid phase and adsorbed on the solid phase at constant temperature and $\mathrm{pH}$ when both phases are in equilibrium. It is essentially a curve, which explains the retention, release, or mobility of adsorbate species from the aqueous to the solid phases at a constant $\mathrm{pH}$ and temperature during an adsorption process. Adsorption equilibrium is the ratio of the amount adsorbed on a surface to that remaining in the solution, while the state of equilibrium is the point at which the adsorbate ions concentrations in the bulk solution and at the liquid-solid interface are in dynamic balance with each other (Somorjai, 1993).

Cd (II) uptake onto Dacryodes edulis seed waste biomass at the temperature considered visibly followed both Langmuir and Freundlich Isotherms (Figures 5 \& 6). However, the Freundlich isotherm gave a better fit. This is evident by the less value of the SSR as shown in Table 3 and suggests multilayer adsorption of the $\mathrm{Cd}$ (II) ions onto heterogeneous binding sites.

The value of the parameter $1 / n$ (the measurement of surface heterogeneity) may be interpreted in a more useful way. When $1 / n<1$, the amount of adsorbed material increases less rapidly than the concentration and implies a chemisorption process; and $1 / n>1$, indicates cooperative adsorption (Haghseresht and Lu, 1998); and when $1 / n=1$, the adsorption equation is equivalent to the distribution law. On the other hand, if $1 / n$ approaches zero (that is becoming more heterogeneous) qe equals $K f$, which amounts to the formation of a monolayer with no further adsorption (Freundlich, 1906; Foo and Hameed, 2010). In this work, $1 / n$ is 0.2614 , which further suggests that the process is a chemisorption process. 
Nigerian Journal of Basic and Applied Science (December, 2020), 28(2): 10-19

Table 2: Values estimated for the parameters of the four kinetics models tested for $\mathrm{Cd}$ (II) adsorption onto Dacryodes edulis biomass.

\begin{tabular}{lll}
\hline $\begin{array}{l}\text { KINETIC/ADSORPTION } \\
\text { ISOTHERM }\end{array}$ & EQUATION & PARAMETERS \\
\hline Pseudo first-order & $\mathrm{q}_{\mathrm{e}}$ & $50.00 \mathrm{mg}$ \\
& $\mathrm{k}_{1}$ & $0.2 \mathrm{~min}^{-1}$ \\
& $\mathrm{SSR}$ & 187.0 \\
Pseudo second-order & $\mathrm{q}_{\mathrm{e}}$ & $50.00 \mathrm{mg}$ \\
& $\mathrm{k}_{2}$ & $0.01 \mathrm{~g} \mathrm{mg}^{-1} \mathrm{~min}^{-1}$ \\
& $\mathrm{SSR}$ & 3.957 \\
Elovich & $\mathrm{A}$ & $7.00 \mathrm{mg} \mathrm{g}^{-1} \mathrm{~min}^{-1}$ \\
& $\beta$ & $1.00 \mathrm{~g} \mathrm{mg}^{-1}$ \\
Intra-particle diffusion & $\mathrm{SSR}$ & 0.7010 \\
& $\mathrm{k}_{\text {id }}$ & $1.00 \mathrm{mg} \mathrm{g}^{-1} \mathrm{~min}^{-0.5}$ \\
& $\mathrm{SSR}$ & 4126.726 \\
\hline
\end{tabular}

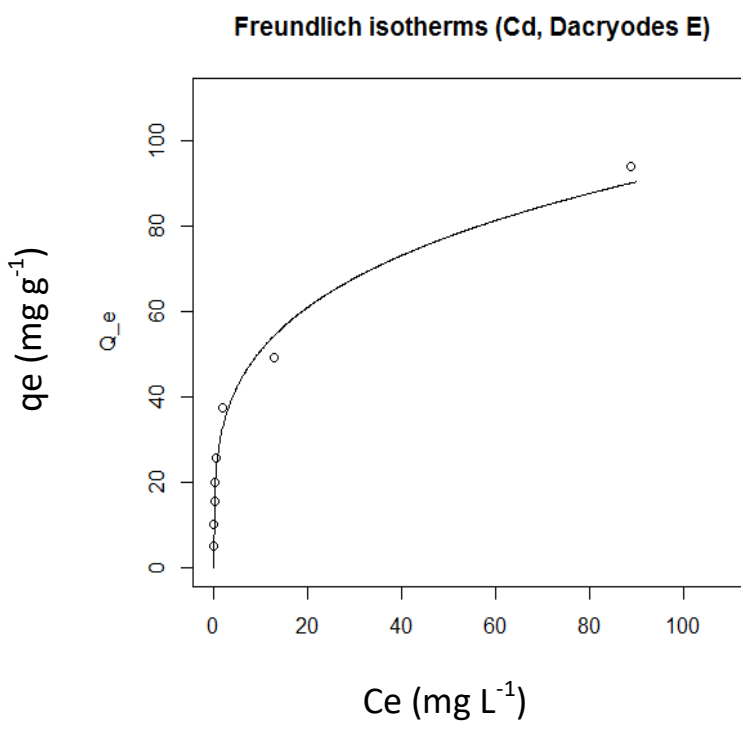

Figure 5: Nonlinear Freundlich isotherm plot for $\mathrm{Cd}(\mathrm{II})$ adsorption onto Dacryodes edulis seed waste biomass.

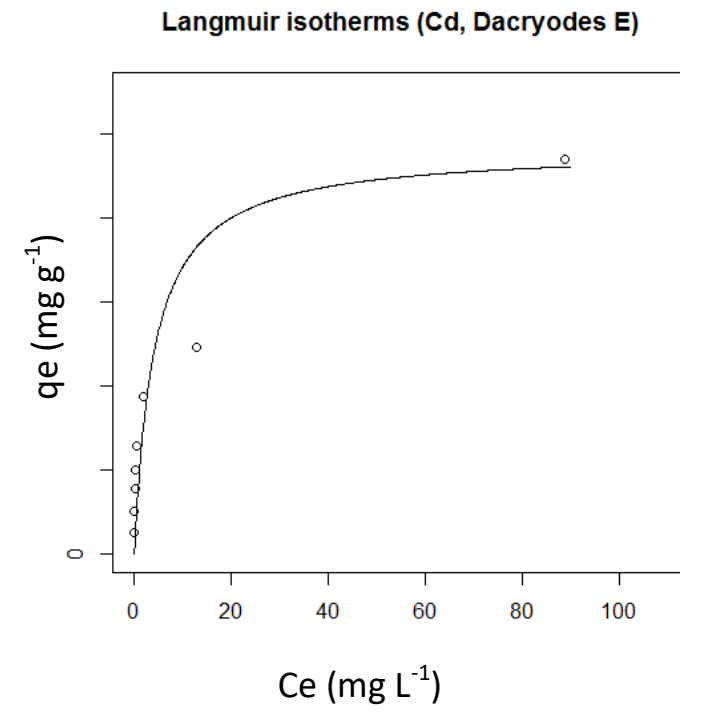

Figure 6: Nonlinear Langmuir isotherm plot for Cd (II) adsorption onto Dacryodes edulis seed waste biomass. 


\section{Overah: Nonlinear Kinetic and Equilibrium Adsorption Isotherm Study...}

Table 3. Langmuir and Freundlich isotherm parameters for the uptake of $\mathrm{Cd}$ (II) onto Dacryodes edulis biomass.

\begin{tabular}{ccccccc}
\hline \multicolumn{3}{c}{ LANGMUIR } & \multicolumn{4}{c}{ FREUNDLICH } \\
\hline $\mathrm{q}_{\mathrm{m}}(\mathrm{mg} / \mathrm{g})$ & $\mathrm{K}_{\mathrm{L}}$ & $\mathrm{SSR}$ & $\mathrm{k}_{\mathrm{f}}\left(\mathrm{mg} \mathrm{g}^{-1}\right)$ & $\mathrm{n}$ & $1 / \mathrm{n}$ & $\mathrm{SSR}$ \\
96.26 & 0.2440 & 1497 & 27.83 & 3.825 & 0.2614 & 125.1 \\
\hline
\end{tabular}

Table 4. A comparison of the $\mathrm{q}_{\max }$ for $\mathrm{Cd}$ (II) adsorption onto various adsorbents.

\begin{tabular}{|c|c|c|c|}
\hline ADSORBENT & $\begin{array}{l}q_{\max } \\
(\mathrm{mg} / \mathrm{g})\end{array}$ & PARAMETERS & REFERENCE \\
\hline $\begin{array}{l}\text { Dacryodes } \\
\text { edulis }\end{array}$ & 96.26 & $\begin{array}{l}\text { Particle size: } 100 \mathrm{um}, \text { Temp: } 28^{\circ} \mathrm{C}, \mathrm{pH}: 7 \text {, } \\
\text { agitation time: } 5 \text { minutes Adsorbent dose: } \\
50 \mathrm{mg}\end{array}$ & This work \\
\hline $\begin{array}{l}\text { Calotropis } \\
\text { procera }\end{array}$ & 8.91 & $\begin{array}{l}\text { Particle size: } 150 \mathrm{um} \text {, Temp: } 27^{\circ} \mathrm{C}, \mathrm{pH}: 5 \text {, } \\
\text { agitation time: } 60 \text { minutes adsorbent dose: } \\
110 \mathrm{mg}\end{array}$ & Babalola et al., 2011 \\
\hline Ficus carcia & 30.31 & $\begin{array}{l}\text { Particle size: } 150 \mathrm{um}, \text { Temp: } 30^{\circ} \mathrm{C}, \mathrm{pH}: 6 \text {, } \\
\text { agitation time: } 80 \text { minute, adsorbent dose: } \\
500 \mathrm{mg}\end{array}$ & Farhan et al., 2013 \\
\hline Maize leaf & 10.18 & $\begin{array}{l}\text { Particle size: } 5000 \text { um, Temp: } 27^{\circ} \mathrm{C} \text {, pH: } \\
\text { 3, agitation time: } 120 \text { minutes, adsorbent } \\
\text { dose: } 500 \mathrm{mg}\end{array}$ & Babarinde et al., 2007 \\
\hline $\begin{array}{l}\text { Scolymus } \\
\text { hispanicus L }\end{array}$ & 54.04 & $\begin{array}{l}\text { Particle size: } 100 \text { um, temp: } 25^{\circ} \mathrm{C} \text {, pH: } \\
\text { 6.5, agitation time: } 60 \text { minutes, adsorbent } \\
\text { dose: } 2000 \mathrm{mg}\end{array}$ & Barka et al., 2010 \\
\hline $\begin{array}{l}\text { Osmundea } \\
\text { pinnatifida }\end{array}$ & 10.02 & $\begin{array}{l}\text { Particle size: } 500 \mathrm{um} \text {, temp: } 23^{\circ} \mathrm{C}, \mathrm{pH}: 5 \text {, } \\
\text { agitation time: } 60 \text { minutes, adsorbent } \\
\text { dose: } 20 \mathrm{~g} / \mathrm{L}\end{array}$ & Hassouni et al., 2014 \\
\hline
\end{tabular}

Comparison of the Capacity of some Biosorbents for Cd (II) Adsorption

Several adsorbents have been employed and reported for the adsorption of $\mathrm{Cd}$ (II) ions from aqueous solution. A comparison of the potentials of some of these adsorbents for $\mathrm{Cd}$ (II) ion adsorption using the values of their respective qmax (Table 4) showed that Dacryodes edulis has a high potential for Cd (II). The difference in qmax for $\mathrm{Cd}$ (II) adsorption onto the various adsorbents may be due to different chemical make-up and surface area of the adsorbents. Besides, different experimental conditions may contribute to the difference in the adsorbent capacity of the various adsorbents for the Cd (II) ion. For example, the Dacryodes edulis particle size used in this study was smaller than those reported for the other adsorbents except Ficus carcia as seen in Table 4. Smaller particle sizes lead to greater surface areas and consequently, better adsorption.

\section{CONCLUSION}

Dacryodes edulis biomass is found in this work to have good prospects for cadmium (II) ion adsorption from aqueous solution. The process is rapid, Pseudo second-order and follows a chemisorption mechanism. Cadmium (II) adsorption using Dacryodes edulis, therefore, promises to be a feasible method for the control of the levels of cadmium ions in effluents and wastewater. It is therefore recommended that further studies be done to evaluate Dacryodes edulis for its potential for $\mathrm{Cd}$ (II) adsorption from real cadmium containing industrial effluents. 


\section{Nigerian Journal of Basic and Applied Science (December, 2020), 28(2): 10-19}

\section{ACKNOWLEDGEMENT}

Loretta C. Overah is grateful to Ofogba Joy and Osiezagha Ewomazino for sample collection and processing.

\section{REFERENCES}

Allen, S.J., Gan, Q., Matthews, R., \& Johnson, P.A. (2003). Comparison of optimised isotherm models for basic dye adsorption by kudzu. Bioresource Technology, 88: 143 152.

Babalola J.O, Overah L.C, Babarinde, A, Oninla, V.O., \& Olatunde, A. (2011). Kinetic, equilibrium and thermodynamic studies on the biosorption of $\mathrm{Cd}$ (II) from aqueous solution by the leaf biomass of Calotropis procera. Journal of Applied Science and Environmental Management, 15 (4): 607-615.

Babarinde, N.A.A., Babalola, J.O., \& Sanni S.O. (2007). Isotherm and thermodynamic studies of the biosorption of $\mathrm{Cd}$ (II) from solution by maize leaf. International Journal of Physical Science, 2: 207-211.

Barka, N., Abdennouri, M., Boussaoud, A., \& El Makhfouk, M. (2010). Biosorption characteristics of cadmium(II) onto Scolymus hispanicus L. as low-cost natural biosorbent. Desalination, 258: 66-71.

Bolster, C. H., \& Hornberger, G. M. (2007). On the use of linearized Langmuir equations. Soil Science Society of American Journal, 71: 1796-1806.

Eyenubo, B. O., \& Overah, L. C. (2018). Biosorption studies of cadmium (II) ions from aqueous solution by Musa paradisiaca stalk, MAMBILLA: Journal of Sciences and Environment, 5(1): 102 - 109.

Farhan, A. M., Al-Dujaili, A. H., \& Awwad, A. M. (2013). Equilibrium and kinetic studies of cadmium (II) and lead(II) ions biosorption onto Ficus carcia leaves. International Journal of Industrial Chemistry, 4:24

Foo, K. Y., Hameed, B. H. (2010). Insights into the modelling of adsorption isotherm systems. Chemical Engineering Journal, 156: 2-10.
Freundlich, H. M. F. (1906). Over the adsorption in solution. Journal of Physical Chemistry 57: 385-471.

Haghseresht, F., \& Lu, G. (1998). Adsorption characteristics of phenolic compounds onto coal-reject-derived adsorbents. Energy Fuels, 12: 1100-1107.

Hammaini, A., González, F., Ballester, A,. Blázquez, M. L., \& Muñoz, J. A. (2007). Biosorption of heavy metals by activated sludge and their desorption characteristics. Journal of Environmental Management, 84: 419-426.

Hamza, I. A. A. Martincigh, B. S., Ngila, J. C., Nyamori, V. O. (2013) Adsorption studies of aqueous $\mathrm{Pb}$ (II) onto a sugarcane bagasse/multi-walled carbon nanotube composite. Physics and Chemistry of the Earth, 66: 157-166.

Hassouni, H., El, Abdellaoui, D., Hani, S. E. L, \& Bengueddour, R. (2014) Biosorption of cadmium (II) and copper (II) from aqueous solution using red alga (Osmundea pinnatifida) biomass. Journal of Material Environmental Science, 5 (4): 967 - 974.

Hynda Y. and Rachida M. (2008). Biosorption of Lead (II) lons From Aqueous Solutions by Biological Activated Dates Stems. Journal of Environmental Science and Technology, 1: 201-213.

Keskinkan, O., Goksu, M. Z., Basibuyuk, M., \& Forster, C.F. (2004). Heavy metal adsorption properties of a submerged aquatic plant (Ceratophyllum demersum). Bioresource Technology, 92(2):197-200.

Kumar, K.V., \& Sivanesan, S, (2005a). Comparison of Linear and non-Linear Methods in Estimating the Sorption Isotherm parameters for Safranin onto Activated Carbon (Short Communication): Journal of Hazardous Materials, B123: 288-292.

Kumar K.V. and Sivanesan S, (2005b). Prediction of optimum sorption isotherm: comparison of linear and non-linear method. Journal of Hazardous Materials. B126: 198-201.

Ogee A., Ellis M., Scibilia B. and Cheryl P. (2013). Adventures in statistics: Curve fitting 


\section{Overah: Nonlinear Kinetic and Equilibrium Adsorption Isotherm Study...}

with linear and nonlinear regression:https://blog.minitab.com/blog/adve ntures-in-statistics-2/curve-fitting-with-linearand-nonlinear regression.

Osmari, T. A., Gallon, R., Schwaab, M., Elisa B., Joao, B. S. and Pinto, J.C. (2013). Statistical Analysis of Linear and Non-linear Regression for the Estimation of Adsorption Isotherm Parameters. Adsorption Science \& Technology, 31( 5): 433 - 458.

Overah L.C. (2011). Biosorption of $\mathrm{Cr}$ (III) from aqueous solution by the leaf biomass of Calotropis procera. Journal of Applied Science and Environmental Management, 15(1) 87- 95.

Overah L.C., \& Odiachi, J. I. (2017). Evaluation of Dacryodes edulis (native pear)seed for $\mathrm{Pb}$ (II) sorption from aqueous solution. Journal of Applied Science and Environmental Management, 21 (1): 186 - 199.

Pagnanelli, F., Trifoni, M., Beolchini, F., Esposito, A., Toro, L., \& Veglio, F. (2001). Equilibrium biosorption studies on single and multi-metal systems. Process Biochemistry, 37:115-124.

Parimal, S., Prasad, M. and Bhaskar, U. (2010). Prediction of equilibrium sorption isotherm: Comparison of linear and non-linear methods Industrial Engineering and Chemical Research, 49: 2882 - 2888.

Rifaqat, A. R. and Moonis A. K. (2002). Biosorption of bivalent metal ions from aqueous solution by agricultural waste: kinetics, thermodynamic and environmental effects. Separation and Purification Technology. 57(2):394-402.

R Development Core Team. (2011). R: A Language and Environment for Statistical Computing. $\mathrm{R}$ Foundation for Statistical Computing, Vienna, Austria. ISBN 3-90005107-0.

Rich, G., and Cherry, K (1987). Hazardous waste treatment technologies, Pudvan publishers, New York.

Sarioglu, M. U., Güler, A. A., \& Beyazit, N. (2009). Removal of copper from aqueous solutions using biosolids. Desalination, 239(13): $167-174$

Somorjai, G. A. (1993). Introduction to Surface Chemistry and Catalysis, John Wiley \& Sons, Inc., New York 177-217.

Volesky, B. (1990). Biosorption of heavy metals in: Biosorbents and biosorption of heavy metals, Ed. B. Volesky. Boca Raton, F. L.: CRC Press 221- 238.

Volesky, B. (1999). Biosorption for the next century, Biohydrometallurgy and the Environment Toward the Mining of the 21st Century, Internat. Biohydrometallurgy Symposium Proceedings, 1999, volume B, Ballester, A. \& Amils, R. (eds.) Elsevier Sciences, Amsterdam, The Netherlands: 161170. 